\title{
BECOMING AN EMPIRICAL DIRECTION OF SUGGESTOLOGY
}

DOI: $\frac{10.31618 / E S U .2413-9335.2020 .12 .74 .818}{\text { Vorontsova Evgeniya Gennadievna }}$

Vorontsova Evgeniya Gennadievna

Candidate of psychological Sciences,

Department of sociology and psychology,

Baikal state University,

664003, Siberian Federal district, Irkutsk region, Irkutsk, 11 Lenin street

Valeeva Yulia Nikolaevna

Specialty student,

Department of sociology and psychology,

Baikal state University,

664003, Siberian Federal district, Irkutsk region, Irkutsk, Lenin street, 11

\section{СТАНОВЛЕНИЕ ЭМПИРИЧЕСКОГО НАПРАВЛЕНИЯ СУГГЕСТОЛОГИИ}

\author{
Воронцова Евгения Геннадвевна \\ Кандидат.психол.н., \\ кафедра соичилогии и психологии, \\ Байкальский государственный университет, \\ 664003, Сибирский федеральньй округ, Иркутская область, \\ 2. Иркутск, ул. Ленина, д. 11, \\ Валеева Юлия Николаевна \\ Студент специалитета, \\ кафедра сочиологии и психологии, \\ Байкальский государственный университет, \\ 664003, Сибирский федеральный округ, Иркутская область, \\ 2. Иркутск, ул. Ленина, д. 11,
}

\section{ABSTRACT}

The article analyzes the problem of suggestion and the branch of suggestion as an empirical direction in science. The main concepts are considered-suggestion, suggestion, suggestion; medical, sociological and psychological aspects of the investigation of suggestion. The main stages of formation and development of suggestology are presented. The article analyzes the pre-scientific, Soviet and modern stages, examines the place of suggestion in modern psychological and pedagogical science, and the influence of suggestive factors on the human psyche. The difficulties of the suggestive approach in the formation of the empirical direction of suggestology are determined.

\section{АННОТАЦИЯ}

В статье проведён анализ проблемы суггестии и станвления суггестологии как эмпирического направления в науке. Рассмотрены основные понятия - внушение, суггестия, суггестология; медицинский, социологический и психологический аспекты рассмотрения суггестии. Представлены основные этапы становления и развития суггестологии. Проанализирован донаучный, советский этап и современный этап, рассмотрено место суггестологии в современнои психолого-педагогической науке, влияние суггестивных факторов на психику человека. Определены трудности суггестивного подхода в становлении эмпирического направления суггестологии.

Ключевые слова: Суггестология, суггестопедия, суггестотерапия, самовнушение, суггестизм, суггестия, этапы становления суггестии.

Key words: suggestion, suggestion therapy, suggestion therapy, auto-suggestion, suggestion, suggestion, stages of suggestion formation.

\section{Введение}

The problem of suggestion occupies a significant place among the many-sided scientific searches devoted to ways and types of influence on the mental sphere of a person.It is also worth noting that, despite the many works of modern researchers, the questions of empirical formation of the science of suggestion are problematic. This is primarily due to the relatively small number of specialists on the problem of suggestion, as well as a relatively small history of the existence of suggestion as a separate direction in psychology. In addition, the relevance of this study is highlighted by the fact that there are currently a small number of scientific papers on this topic.

The practical significance of the research lies in the fact that the analysis of sources will allow us to clarify the idea of suggestology, to separate the terms and expand them, to build a historical chronology of events. This article can be used in educational institutions when studying the problems of suggestion and auto-suggestion.

The purpose of the article is to examine the representation of suggestology in science, to study the 
presuppositions of its origin, and to analyze the empirical direction of suggestology in modern science.

Let's look at what should be understood by the terms suggestology, suggestopedia, and suggestion. Suggestology is a separate branch of psychology that studies the mechanisms of suggestion, hypnosis, both at a distance and near, both mentally and verbally, and ways of its practical application.

The term "suggestopedia" refers to a system of accelerated learning based on the use of hypnosis [2, c. 17-19].

Suggestion is a psychological influence on a person's consciousness, in which there is not a critical perception of their beliefs and attitudes, but a suggestion, let's say, because of the authority of the individual [2, p. 17-19].

The article presents the stages and contents of scientific views on suggestology. The study of the historical discourse of the phenomenon of suggestion and suggestive practices in the scientific community became more active in the period of the late XIX-early $\mathrm{XX}$ century. XX century. This was due to attempts to search for philosophical reasons. The actualization of this problem in this period is not accidental: the questions of suggestion and its impact on the individual were formulated at the turn of the century, within the framework of the formation of globalization processes. At this point, it was discovered that there is a need for effective communication levers of influence. Thus, W. J. Sidis in The book "Psychology of suggestion", the author describes "the study of the subconscious nature of man", where he focuses on the role of suggestion and suggestibility in the phenomenology of various mass phenomena. For example, the effect of panic in the crowd, "mental epidemics" and demonophobia of the middle ages, financial crises and stock market panics, mass expectations of the "end of the world".

Another well-known scientist V. M. Bekhterev in 1897 posed the problem of studying the role of suggestion in society, in which the author emphasizes the importance of suggestion research: "... suggestion is an important factor in social life and should be the subject of study not only by scientists in the field of medical Sciences, but also by researchers of other branches of knowledge analyzing the living conditions of society and its laws» [2, p. 17].

Suggestion is studied in several aspects: medical, sociological, and psychological.

In the medical aspect, suggestology is used as a method of action in hypnosis. In the sociological aspect, suggestology is studied within the framework of influencing the masses of people. In psychology, suggestology is considered as a branch of psychotherapy.

The definition of Bekhterev is still relevant: suggestion should be understood as the effect of one person on another, produced intentionally or unintentionally on the part of the influencing person and that can occur unnoticeably or with his knowledge and consent» [2, p. 15-16].

In his work "Suggestion and education", Bekhterev described the meaning of suggestion and drew attention to the fact that the interaction of adults with a child includes both negative elements of the suggestive and the negative influence: child mental epidemics, outbreaks of unmotivated violence, the imposition of suicidal moods (modern "Blue whale"), the spread of sexual perversions .

Currently, interest in the subject of suggestion has grown dramatically, and in the social aspect, primarily due to the analysis of the psychology of informal communities in the real and virtual world.

The act of suggestion is based on the mental quality of suggestibility. In its most General form, suggestibility is a person's ability to receive suggestion. If suggestion is a method of influence, then suggestion is the degree of susceptibility to suggestion [7, p. 6].

Suggestibility - a normal property of higher nervous activity, in varying degrees inherent in all people.

Suggestibility depends on age, gender, intelligence, health status, and other factors. It can fluctuate depending on the type of suggestion and the authority of the person who conducts the suggestion. Suggestibility as a manifestation of individuality is not unconditional, but conditional; not stable, but dynamic [7, p. 6-10].

Modern psychological and pedagogical science, without overestimating the role of unconscious factors, asserts the reality of the influence of suggestive factors on the human psyche.

Stages of formation and development of suggestology.

Next, we will consider the main stages of formation and development of suggestology [7. p. 10].

At the first stage of formation, methods of research of suggestology were considered (2 half of the XVIII century - the beginning of the XIX Century). its development Began when the Viennese doctor Franz Anton Mesmer used hypnosis to treat nervous patients. At first, he explained "magnetism" - as hypnotic sessions were then called-as"universal gravitation".Later, he became convinced that a magnet was not necessary for conducting hypnosis sessions. He and his followers tried to explain the phenomena of hypnosis by "vibes", allegedly emanating from one person and transmitted to another. Research and implementation of hypnosis took place in European countries, primarily in France, where Russian researchers got acquainted with it.

At the second stage, methods of suggestion were introduced into practical activity (C. XVIII-XIX century). In our country, the doctrine of hypnosis as a therapeutic method is associated with the name of $\mathrm{V}$. M. Bekhterev, who in 1884 , following an internship at the Salpetriere hospital with J. Charcot in Paris, achieved the removal of the official ban on the use of hypnosis [Bekhterev,1911,p.36].

With the help of the suggestive method, V. M. Bekhterev developed methods of suggestion, indirect suggestion, auto-suggestion, collective suggestion and distracting psychotherapy, all of which are presented in his work "Hypnosis, suggestion and psychotherapy and their therapeutic significance".

In addition To V. M. Bekhterev, the study of theoretical and practical aspects of the use of hypnosis is presented in the works of V. ya. Danilevsky, A. A. Tokarsky and their followers [Stepanov, 2016, p. 53]. 
At the third stage, the use of suggestive methods in Soviet Russia (1917-1970) was reviewed. Despite the widespread use of the method of hypnosis in the Russian Empire, in 1924. The people's health Committee of the RSFSR issued a restrictive instruction on its use. currently, hypnotization was allowed only for medicinal purposes and only to specialists with the participation of medical personnel, a relative of the patient. All manipulations were reflected in the patient's medical history and in the accounting book. Along with the use of suggestive methods, the Soviet practice actively used techniques of rational psychotherapy, described as methods of "reeducation treatment" to strengthen the will and form new associations. In the course of the practice, the importance of forming high moral views in the patient by persuading them to strengthen the patient's "Self" or refocus on other tasks and activities is emphasized.

Then in 1931 I. p. Pavlov, at the laboratory of LSU, founded two specialized clinics - the nervous and psychiatric, where different forms of neuroses and psychoses were studied. Conditional-reflex theory made it possible to justify the methods of explanation, persuasion, and suggestive influence. In the theory of I. p. Pavlov, it is shown that they affect the dynamic cortical processes, changing the patient's consciousness, his emotional sphere, endocrinevegetative and other physiological processes in the right direction.

In addition, the role of K. I. Platonov (1941), V. E. Rozhnov (1953), P. I. bul (1964) and others should be highlighted in the development of Pavlov's school of psychotherapy.

Later it became the natural appearance of other suggestive methods and techniques: negative selfhypnosis by M. D. Tantsura (1956), motivated the suggestion by $\mathrm{N}$. In. Ivanov (1959), imperative suggestion awake due to severe emotional stress stuttering by V. M. Shklovsky (1966).

In the period from the $40 \mathrm{~s}$ to the mid-70s, the practice of hypnotization by telephone, television and radio broadcasting was analyzed, and combined methods of psychotherapy were developed, with a combination of suggestion and other pharmacological and physiotherapy methods of treatment.

In the mid-1950s, the first conference on psychotherapy in the USSR was held. among its tasks was the exchange of experience and scientific research of Soviet scientists in the field of psychology and psychiatry.

At this conference, in his speech, I. Z. Velvovsky ("Psychotherapy and psychoprophylaxis in the light of nervism in obstetrics and gynecology") presented the periodization of the evolution of psychotherapy in Russia, highlighting 2 stages: a) dopavlovsky (including Sechenovsky), b) Pavlovsky (neurodynamic evolutionary-nervist concepts). Most of the conference reports were devoted to the use of suggestive methods, along with techniques of explanation and persuasion. At the same time, K. I. Platonov emphasized that,despite the growth in the number of theoretical developments in Soviet Russia, organizational aspects leave much to be desired, that is, despite the existing data, it is worth continuing to conduct research and development.

At the fourth stage, suggestopedia is formed (1970-1990). This is due to the fact that during this period the student's personality was Central in the process of professional training. Suggestopedia as a method was developed by a psychotherapist, teacher G. Lozanov. According to Lozanov, information from the outside can penetrate into the inner world of the individual through the conscious and unconscious in the psyche.The second, unconscious, involves activating the reserve mental capabilities of the student in the educational process, for example, in the process of learning foreign languages.

In medical practice, G. Lozanov discovered the reserve capabilities of the person in the unconscious mental sphere and attributed to them: memory reserves, intellectual activity; positive emotions, experiences that relieve feelings of fatigue. G. Lozanov defined" suggestology "as" the science of releasing hidden human capabilities", and the success of suggestopedia is explained by the decisive role of direct effects in the state of pseudo-anxiety, and not by the organization of students ' activities. This approach has reoriented the motivation system and the learning process, helping to increase its effectiveness.

B. D. Karvasarsky, studied the problems of suggestion in the learning process, based on suggestology as an approach to learning. Experimental data obtained by the psychotherapist show an increase in the effectiveness of learning material assimilation by 29 times due to the activation of the mechanism described above.

The subject of research by scientists O. K. Tikhomirov, V. L. Raikov, and N. A. Berezanskaya (1975) was "creative thinking" and "training in creative activity (IS) in hypnosis", during which the conclusion was made: "the Reproduction of knowledge is limited by suggestion, as well as by the past practices of the subject... The condition for changing the personality is the presence of a system of knowledge about the subject's self-image... when such knowledge is not enough, the behavior is passive, wary, confused... when it is sufficient, the subject has a state of uplift, active actions, and emotionality" [16, p. 28-31.]

According to N. p. Dubinin, the difficulties of the suggestive approach are associated with the place of "dark, instinctive tendencies" in the learning process [9, p.224-225].

Agreeing with the presence of these tendencies in the individual, it is impossible to talk about their essential role in the mental life of the cultural personality, since the appearance of consciousness and the manufacture of tools at a certain stage of biological evolution led to the fact that the instincts "lost their adaptive functions"; a "social form of inheritance" was formed, and it "began to shape human biology" [9, p.108-109].

The next problem is related to the role of the suggestive beginning in secondarily automated actions. These actions go through the conscious stage to automatism and are consciously controlled by the overlying level ("this level is the leading one for this movement ... and regardless of the height, it is only 
realized... leading level", - as noted by N. A. Bernstein) [8, p. 101]. Such statements are all the more true for psychic actions proper.

In other words, a suggestion is a message that the hypnotist addressed to the subjects, and, like any message, it is aimed at changing the feelings, thoughts, and behavior of the recipients in a special way.

At the fifth stage, we will consider the development of suggestology at this point in time.

Today, suggestive influence is often called psychological influence, thus contrasting "rational" and "psychological". This contrast is not quite correct. A conversation where there is an appeal to reason and logic - in a broad sense, it is also quite a psychological influence. But in the ordinary view of psychological influence, it is customary to speak where a direct appeal to reason and logic is not enough, where a more subtle influence is needed.

In the present reality, the phenomenon of suggestion is often used in psychological consultations. Psychological consultations can be carried out both in a reasonable form and in the form of suggestive influence [8, p. 66-67].

If the consultation takes place in the form of suggestive psychotherapy, it includes: contact; listening to the complaint and building hypotheses; testing the hypothesis and getting a pronounced emotional negative reaction to it (haste, confidence of denial); conducting suggestion.

The result is not summed up, since this would be an exit to a conscious plan, or false results are summed up. Only the consultant knows what was done [7, p. 510]. Thus, based on the data obtained in the course of a number of studies, currently suggestology has actually developed as a separate branch of psychology. Over the past $10-15$ years, the following has been identified:

1. The subject gives a response to the suggestion in spite of their own will. For example: the subject responds to repeated suggestions of lightness of hands and raising of hands, raises his hand, but accepts this action as independent of his will, and considers the hand as "rising by itself".

2. Suggestion can be enhanced by working with the imagination. In fact, one can argue that the response of the subject to the suggestion is always accompanied by the imagination [10, pp. 6-7].

The suggestion of raising the hand can be accompanied by representations of a balloon, and the rope is wrapped around the wrist and pulls. Similar suggestion numbness of the hand can be enhanced by a fantasy where the hand is immersed in a bucket of ice and water. An imaginary crossing over a fog-shrouded bridge may accompany the suggestion of regression to the stage of childhood.

Suggestion is a multi-modal phenomenon. Raising the hand is an example of a suggestion that affects motor skills, called ideomotor; the prefix "ideo" indicates that the subject responds to the idea of moving the hand. Another example of ideomotor suggestion is the oblique-positional suggestibility test: the experimenter draws attention to his natural ability to deviate posteriorly or anteriorly.

Suggestions are prescribed to increase the amplitude so that the subject is more and more fed to the experimenter (he is ready to prevent the subject from falling).

Ideosensory suggestions are found in the handraising tests ("the hand feels lighter and lighter") and in the relaxation instructions ("You feel your body more and more heavy and relaxed"). Also, suggestions can be addressed to the olfactory modality (positive: "In a second you will feel an exceptionally terrible smell in your nostrils"; or negative (checking with a solution of ammonia): "You have lost your sense of smell"). Similar positive and negative suggestions can be formed relative to the taste modality [6, p. 28].

Today, there are different types of suggestion: suggestion and autosuggestion, direct or open, indirect or closed; contact and distant.

In psychotherapy, appropriate techniques of suggestion are used in waking and natural, hypnotic and narcotic sleep. Suggestion in wakefulness is present to a certain extent in every patient's doctor's appointment, and can serve as an independent psychotherapeutic influence.

The formula of suggestion is usually pronounced in an imperative tone, taking into account the condition of patients and the nature of clinical manifestations of the disease. They can be directed both to improve overall health (sleep, appetite, performance), and to eliminate some neurotic symptoms.

Usually, before the suggestion in reality, there is an explanatory conversation about the essence of the therapeutic suggestion and the patient is convinced of its effectiveness. The effect of suggestion is the stronger, the higher in the eyes of the patient the authority of the doctor who made the suggestion.

The degree of implementation of suggestion identify the specific personality traits of the patient,the severity of the "magic" attitude, belief in ability to influence one person to the other through unknown means and methods. Suggestion in a state of hypnotic sleep for psychological purposes is widespread [3, p. 88-89]. Thus, when using the method of narcopsychotherapy, the effect of suggestion is realized in the conditions of artificially induced narcotic sleep. Similar methods include the use of a gas mixture of oxygen and nitrous oxide.

Indirect suggestion -a subspecies of suggestion, where its content is supported by a strictly defined and specific condition under which it will be implemented. In indirect suggestion, additional stimuli are used, which acquire a new informational role due to the direct suggestion being made. This form of suggestion is the basis of mediating and potentiating psychotherapy $[8$, p. 66-67].

The client's confidence in the therapeutic effect is an active factor, and it plays a great role in working with the patient. A favorable General environment, the psychologist's strengthening of hope for the effectiveness of the procedure increases its impact. The mechanism of "armed suggestion", "subjective" suggestion or indirect psychotherapeutic effect (Bekhterev) must be kept in mind when using any psychological and psychotherapeutic effects, including biological ones [13, p. 208].

The study of the above issues will allow you to apply suggestive methods without ignoring or 
overestimating them. At the same time, contribute to the further improvement of teaching practice.

\section{Conclusion}

The article presents 5 stages of development and formation of suggestology. At the first stage, methods of investigation of suggestion, in particular hypnosis, were considered. At the second stage, the methods of suggestology were introduced into practice, namely in medicine. At the third stage, the use of suggestive methods in the USSR was revised. The fourth stage is the formation of suggestopedia (1970-1990). the Fifth stage is the development of suggestology in modern science (the last 10-15 years).

The presence of suggestive methods in psychological work can have a positive effect on the indicator of the level of cheerfulness, efficiency and motivation. The use of non-Directive suggestive methods has a positive impact on indicators such as well-being, activity and mood of clients; it leads to an improvement in the emotional state, affecting various processes, for example, the emotional sphere: reducing anxiety; increasing calmness; increasing energy levels; self-confidence; States of elation. The subject reacts to the suggestion regardless of its own will. Suggestions can be significantly enhanced by the corresponding work of the imagination. Hypnotic suggestions can affect specific physiological responses, such as physical processes controlled by the autonomic nervous system (ANS) and therefore not subject to conscious control. Suggestion is not a single concept. Suggestions may differ in the way they are implemented. Suggestibility can be reliably measured.

\section{Bibliography}

1. Arshavsky M. A. about the session of "two Academies" / / repressed science. SPb:Nauka, 1994, Issue 2, Pp. 239-242.

2. Bekhterev V. M. Hypnosis, suggestion and psychotherapy and their therapeutic value. - SPb, 1911. $-61 s$.

3. Bondarenko A. F. Psychological help. Moscow: Klass, 2001. - 180 p.

4. Bratus B. S. Russian, Soviet, Russian psychology. - Moscow: flint, 2000. - 120s.

5. bul P. I. Fundamentals of psychotherapy. - L.: Medicine, 1974. - 220s.

6. Burlachuk L. F. Psychotherapy. - SPb:Peter, 2014. - 134c.

7. Vasilyuk F. E. Korneva E. N. New name. New status. New tasks / / Advisory psychology and psychotherapy. - 2010. - № 1. - P. 5-10.

8. Gulina M. A. Therapeutic and Advisory psychology. - SPb: Rech, 2001. - 78s.

9. N. p. Dubinin and the XX century / Comp. L. G. Dubinina. - Moscow: Nauka, 2006. - 746 p.

10. Ivanov N. V. the Emergence of domestic psychotherapy: autoref. dis. ... doctor of medical Sciences, 1954. - 15s.

11. Karvasarsky B. D. Clinical psychology. - Saint Petersburg: Piter, 2012. - 360C.
12. Lozanov G. K. Suggestology and suggestopedia: abstract dis. for the degree of doctor of medicine (14.767) / Kharkiv medical Institute-Sofia: [b. I.], 1970-64 p.

13. Lebedinsky M. S. Essays of psychotherapy. M.: Medicine, 1971. - 320S.

14. Psychotherapeutic encyclopedia / ed. by B. D. Karvasarsky. - Saint Petersburg: Piter, 2006. - 112s.

15. Stepanov R. V. Historical review of the concept of hypnotic trance / / Central scientific Bulletin. - 2016. - Vol. 14. - P. 52-53.

16. Shvetsova E. Yu. Ways to improve the effectiveness of treatment of anxiety disorders in the practice of a neurologist// Central scientific Bulletin, 2016, Vol. 1. - №1(1). - Pp. 28-31.

\section{Библиография}

1.Аршавский М.А. О сессии «двух Академий» // Репрессированная наука. СПб:Наука, 1994. Вып. 2. - С. 239-242.

2.Бехтерев В.М. Гипноз, внушение и психотерапия и их лечебное значение. - СПб,1911. $-61 \mathrm{c}$.

3.Бондаренко А.Ф. Психологическая помощь. - М.:Класс,2001. - 180 с.

4.Братусь Б.С. Русская, советская, российская психология. - М.: Флинта, 2000. - 120с.

5.Буль П.И. Основы психотерапии. - Л.: Медицина, 1974. - 220с.

6.Бурлачук Л.Ф. Психотерапия. - СПб:Питер, 2014. - 134c.

7.Василюк Ф.Е. Корнева Е.Н. Новое имя. Новый статус. Новые задачи // Консультативная психология и психотерапия. - 2010. - № 1. - С. 510 .

8.Гулина М.A. Терапевтическая и консультативная психология. - СПб: Речь, 2001. $78 \mathrm{c}$.

9.Н.П. Дубинин и ХХ век/ Сост. Л. Г. Дубинина.- М.: Наука, 2006. - 746 с.

10. Иванов Н.В. Возникновение отечественной психотерапии: автореф.дис. ... докт. мед. наук, 1954. - 15c.

11. Карвасарский Б.Д. Клиническая психология. - Спб: Питер, 2012. - 360с.

12. Лозанов Г. К.Суггестология и суггестопедия: Автореферат дис. на соискание ученой степени доктора медицинских наук. (14.767) / Харьк. мед. ин-т. - София: [б. и.], 1970. $64 \mathrm{c}$.

13. Лебединский М.С. Очерки психотерапии. М.: Медицина, 1971. - 320с.

14. Психотерапевтическая энциклопедия / под ред. Б.Д. Карвасарского. - СПб: Питер, 2006. $112 \mathrm{c}$.

15. Степанов Р.В. Исторический обзор понятия о гипнотическом трансе // Центральный научный вестник. - 2016. - Т. 14. - С. 52-53.

16. Швецова Е.Ю. Пути повышения эффективности терапии тревожных расстройств в практике невролога// Центральный научный вестник. - 2016. - Т. 1. - №1(1). - С. 28-31. 